\title{
Disproportionately Large Communicating Fourth Ventricle: Pearls for Diagnosis and Management
}

\author{
Aswin Chari $^{1}{ }^{\text {, Dimitrios Karponis }}{ }^{2}$, Claudia L. Craven ${ }^{3}$, Akbar A. Khan ${ }^{4}$, Lewis Thorne ${ }^{3}$ \\ 1. Neurosurgery, Imperial College London, London, GBR 2. Orthopaedics, Imperial College London, London, GBR 3. \\ Neurosurgery, National Hospital for Neurology and Neurosurgery, London, GBR 4. Neurosurgery, Queen Elizabeth \\ University Hospital, Glasgow, GBR
}

Corresponding author: Dimitrios Karponis, dimitriskarponis@gmail.com

\begin{abstract}
\section{Introduction}

Disproportionately large communicating fourth ventricle (DLCFV) is an unusual presentation of communicating hydrocephalus, in which patients with hydrocephalus have a disproportionately enlarged fourth ventricle in the absence of obstructive pathology. We present six cases of DLCFV which, to date, is the largest series of this relatively rare condition. We highlight the significance of diagnosis and its differentiation from trapped fourth ventricle (TFV) and discuss the nuances for optimal management of DLCFV.
\end{abstract}

\section{Methods}

Retrospective case series of consecutive patients with DLCFV, managed by the senior author (LT) over a 10year period.

\section{Results}

Six cases were identified, five of whom had previous posterior fossa surgery and one with previous encephalitis. All patients presented with cerebellar signs, the initial group had unsuccessful initial management with typical cerebrospinal fluid (CSF) diversion. Consistent symptom resolution was achieved by the application of negative CSF pressures via external ventricular drainage (EVD), maintained with subsequent ventriculopleural shunt (VPL), valveless lumbopleural shunt (LPS) or valveless ventriculoperitoneal shunt (VPS), or proceeding directly to a low-pressure system.

\section{Conclusions}

DLCFV is a diagnosis characterised by cerebellar dysfunction, with or without cranial nerve palsies, often in the setting of previous posterior fossa pathology. Optimal management relies on knowledge of this unique diagnostic entity, and use of an EVD at negative pressures to confirm symptomatic and radiological

Received 07/10/2018

Review began 07/16/2018 Review ended 10/29/2018 Published 11/05/2018

\section{๑) Copyright 2018}

Chari et al. This is an open access article distributed under the terms of the Creative Commons Attribution License CC-BY 3.0., which permits unrestricted use, distribution, and reproduction in any medium, provided the original author and source are credited. improvement prior to definitive treatment.

Categories: Neurosurgery

Keywords: communicating hydrocephalus, fourth ventricle, negative pressure shunting, ventriculopleural shunt

\section{Introduction}

Communicating hydrocephalus can occur as a result of a number of different pathological processes and is usually characterised by proportionate enlargement of the lateral, third and fourth ventricles [1]. A subgroup of patients with communicating hydrocephalus have a fourth ventricle that is enlarged to a greater extent than the lateral and third ventricles, in the absence of an obstructive pathology. This phenomenon, termed disproportionately large communicating fourth ventricle (DLCFV) was first documented in 1978. Subsequently a limited number of case reports have been published, almost exclusively in the Japanese literature $[2-15]$.

The majority of the aforementioned patients present with cerebellar signs (ataxia and nystagmus) and cranial nerve palsies, and often without the traditional signs and symptoms of raised intracranial pressure (headache, nausea, vomiting, altered consciousness and papilloedema). Treatment is often difficult and patients either undergo multiple shunt revisions or require additional procedures prior to symptom resolution $[2-5,7,8,10,11,13]$.

Effective management depends on early identification of the condition. It is easy to mistake this entity for a more common communicating hydrocephalus or an isolated fourth ventricle. This is likely to lead to treatment failure or an unnecessary attempt to cannulate the fourth ventricle. Our case series demonstrates that this is a distinct entity characterised by a low-pressure state in patients who are likely to have altered 


\section{Cureus}

compliance in the posterior fossa, either through disease or previous intervention.

We present a retrospective case series of DLCFV, outlining the aetiology, clinical and radiological findings and outcomes for these patients. We present a novel treatment paradigm for this condition, which results in consistent radiological and symptomatic improvement, without a need for multiple surgical interventions and shunt revisions.

\section{Materials And Methods}

Consecutive cases of DLCFV managed by the senior author (LT) over the last 10 years (2006-2015) were retrospectively identified (Figure 1). Case notes and imaging were retrospectively examined to identify the aetiology, clinical and radiological presentation, treatment and outcomes for these patients.

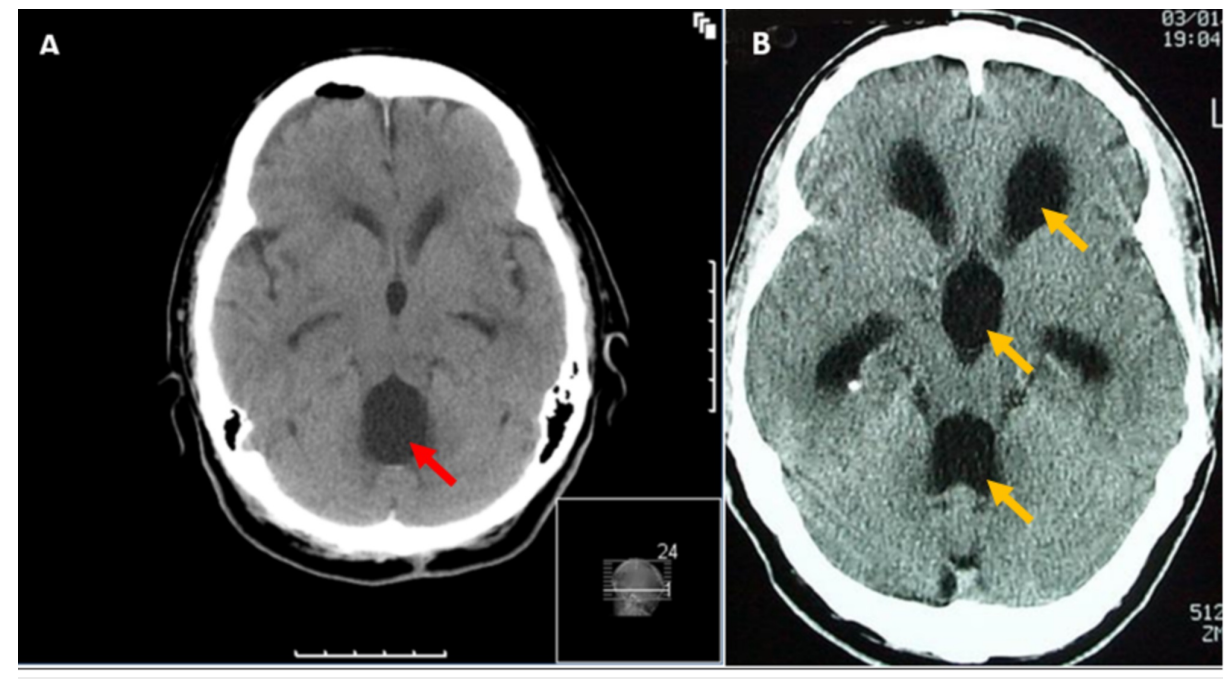

FIGURE 1: Typical CT image of DLCFV (A) compared with the proportionate enlargement of all ventricles more often seen in a communicating hydrocephalus (B). Note that in DLCFV only the fourth ventricle is disproportionately enlarged (as shown by the red arrow), compared to a universal enlargement (as shown by the yellow arrows).

CT: Computed tomography; DLCFV: Disproportionately large communicating fourth ventricle.

\section{Results}

\section{Clinical characteristics}

Six cases were identified. The patient characteristics are summarised in Table 1. Five patients had posterior fossa surgery with past interventions prior to presentation with DLCFV and one patient had previous encephalitis. There were no cases of idiopathic DLCFV. The patient presentation was characterised by cerebellar signs (ataxia, nystagmus and nausea). After presentation, four patients were initially treated with ventriculoperitoneal shunt (VPS) (programmable system incorporating an anti-siphon device) or shunt revision (SR); none of these patients experienced symptomatic improvement and showed persistent fourth ventriculomegaly. 


\section{Cureus}

\begin{tabular}{|c|c|c|c|c|c|c|}
\hline Patient & Aetiology & $\begin{array}{l}\text { Clinical } \\
\text { Presentation }\end{array}$ & $\begin{array}{l}\text { Radiological } \\
\text { Presentation }\end{array}$ & Initial Treatment & $\begin{array}{l}\text { Subsequent Temporary } \\
\text { Treatment }\end{array}$ & $\begin{array}{l}\text { Definitive } \\
\text { Treatment }\end{array}$ \\
\hline 1 & $\begin{array}{l}\text { Post fossa } \\
\text { craniectomy for } \\
\text { resection of } \\
\text { recurrent } \\
\text { craniocervical } \\
\text { junction } \\
\text { meningioma }\end{array}$ & $\begin{array}{l}\text { Eight months } \\
\text { post resection - } \\
\text { Ataxia, } \\
\text { somnolence }\end{array}$ & DLCFV & $\begin{array}{l}\text { VPeS insertion and revision } \\
\text { following persistent } \\
\text { ventriculomegaly }\end{array}$ & $\begin{array}{l}\text { EVD resulted in ventricular } \\
\text { collapse and when EVD set } \\
\text { below } 0 \mathrm{~cm} \mathrm{H} \mathrm{H}_{2} \mathrm{O}\end{array}$ & vVPeS \\
\hline 2 & $\begin{array}{l}\text { Post fossa } \\
\text { craniectomy for } \\
\text { clipping of PICA } \\
\text { aneurysm + } \\
\text { ventriculoperitoneal } \\
\text { shunt insertion }\end{array}$ & $\begin{array}{l}\text { Rebleed and } \\
\text { shunt producing } \\
\text { acute shunt } \\
\text { failure - } \\
\text { Headache, } \\
\text { ataxia, } \\
\text { nystagmus }\end{array}$ & DLCFV & $\begin{array}{l}\text { VPeS revision } \times 2 \text { following } \\
\text { persistent ventriculomegaly }\end{array}$ & $\begin{array}{l}\text { EVD with ventricular } \\
\text { collapse and symptomatic } \\
\text { improvement when EVD set } \\
\text { below } 0 \mathrm{~cm} \mathrm{H}_{2} \mathrm{O}\end{array}$ & $\begin{array}{l}\text { Ventriculopleural } \\
\text { shunt } \\
\text { incorporating } \\
\text { fixed low- } \\
\text { pressure } \\
\text { differential } \\
\text { pressure valve }\end{array}$ \\
\hline 3 & HIV encephalitis & $\begin{array}{l}\text { Ataxia, } \\
\text { somnolence, } \\
\text { facial palsies, } \\
\text { nystagmus }\end{array}$ & DLCFV & $\begin{array}{l}\text { VPeS insertion and revision } \\
\text { x2 following persistent } \\
\text { ventriculomegaly of fourth } \\
\text { ventricle }\end{array}$ & $\begin{array}{l}\text { EVD with ventricular } \\
\text { collapse and symptomatic } \\
\text { improvement resulting from } \\
\text { progressive lowering of EVD } \\
\text { pressure, final setting - } 20 \\
\mathrm{~cm} \mathrm{H}_{2} \mathrm{O}\end{array}$ & vVPeS \\
\hline 4 & $\begin{array}{l}\text { Post fossa } \\
\text { craniectomy for } \\
\text { vestibular } \\
\text { schwannoma }\end{array}$ & $\begin{array}{l}\text { Presented three } \\
\text { months post } \\
\text { procedure with } \\
\text { headache, } \\
\text { nausea and } \\
\text { vomiting }\end{array}$ & DLCFV & $\begin{array}{l}\text { VPeS insertion and revision } \\
\text { with persistent } \\
\text { ventriculomegaly of fourth } \\
\text { ventricle }\end{array}$ & & $\begin{array}{l}\text { Programmable } \\
\text { lumber } \\
\text { peritoneal shunt }\end{array}$ \\
\hline 5 & $\begin{array}{l}\text { Foramen magnum } \\
\text { decompression for } \\
\text { Chiari I } \\
\text { malformation }\end{array}$ & $\begin{array}{l}\text { Ataxia, } \\
\text { nystagmus }\end{array}$ & DLCFV & $\begin{array}{l}\text { EVD with ventricular } \\
\text { collapse and symptomatic } \\
\text { improvement resulting from } \\
\text { progressive lowering of EVD } \\
\text { pressure, final setting - } 10 \\
\mathrm{~cm} \mathrm{H}_{2} \mathrm{O}\end{array}$ & & $\begin{array}{l}\text { Ventriculopleural } \\
\text { shunt } \\
\text { incorporating } \\
\text { fixed low- } \\
\text { pressure } \\
\text { differential } \\
\text { pressure valve }\end{array}$ \\
\hline 6 & $\begin{array}{l}\text { Vestibular } \\
\text { schwannoma } \\
\text { treated with } \\
\text { stereotactic } \\
\text { radiosurgery }\end{array}$ & $\begin{array}{l}\text { Ataxia and } \\
\text { nystagmus }\end{array}$ & DLCFV & $\begin{array}{l}\text { Lumbar drain with } \\
\text { ventricular collapse and } \\
\text { symptomatic improvement } \\
\text { resulting from progressive } \\
\text { lowering pressure, final } \\
\text { setting }-10 \mathrm{~cm} \mathrm{H2O}\end{array}$ & & $\begin{array}{l}\text { Programmable } \\
\text { lumber } \\
\text { peritoneal shunt }\end{array}$ \\
\hline
\end{tabular}

TABLE 1: Presenting aetiology, symptoms and treatment of six patients in this series with DLCFV.

vVPeS: valveless ventriculoperitoneal shunt; DLCFV: Disproportionately large communicating fourth ventricle; EVD: External ventricular drainage; HIV: Human immunodeficiency virus; PICA: Posterior inferior cerebellar artery.

\section{Intervention}

In four patients, temporary treatment with an external ventricular drain (EVD) or lumbar drain (LD) was employed. Symptomatic improvement and corresponding resolution of fourth ventricular enlargement occurred only when the drain was set below $0 \mathrm{~cm} \mathrm{H}_{2} \mathrm{O}$; in one case, this was as low as $-20 \mathrm{~cm} \mathrm{H}_{2} \mathrm{O}$.

Definitive treatment, therefore, sought to establish a low-pressure system capable of maintaining negative pressures. This was in the form of a valveless ventriculoperitoneal shunt (vVPS; two patients), a ventriculopleural shunt (two patients) or a lumboperitoneal shunt (LPS; two patients).

\section{Clinical and radiological outcome}




\section{Cureus}

All patients improved symptomatically following low-pressure cerebrospinal fluid (CSF) diversion, with complete resolution of ataxia, nystagmus and somnolence. No patients required further revision or intervention after low-pressure CSF diversion.

Figure 2 shows examples of fourth ventricular size at presentation in two patients (A and D), after initial VPS (B and E) and following subsequent treatment with vVPS (C) or lumboperitoneal shunt (F).

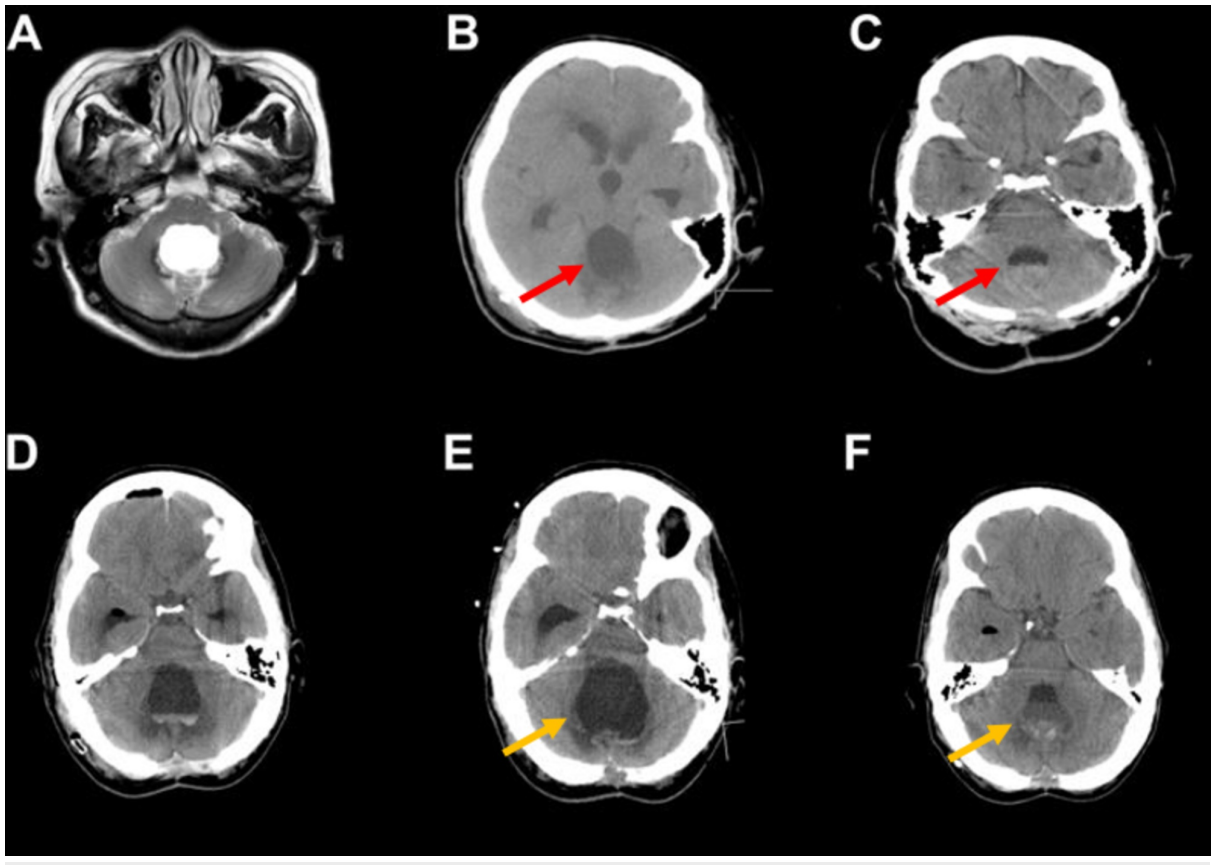

FIGURE 2: Example of two patients with DLCFV at the time of presentation ( $A$ and $D$ ), after ventriculoperitoneal shunting ( $B$ and $E$ ) and after definitive treatment with a low-pressure system; valveless ventriculoperitoneal shunt $(C)$ or ventriculopleural shunt $(F)$. Note that both patient $A$ (red) and $D$ (yellow) show markedly reduced size of their fourth ventricle following low pressure shunting ( $C$ and $F$ ), unlike with traditional ventriculoperitoneal shunting ( $B$ and $E$ ).

DLCFV: Disproportionately large communicating fourth ventricle

\section{Discussion}

We present six cases of DLCFV which, to date, is the largest series of this relatively rare condition. Optimal management was achieved through negative pressure CSF diversion. We highlight the potential pitfalls, salient points and pearls in the management of DLCFV.

\section{Presentation of DLCFV}

In our case series, DLCFV occurred in patients with previous posterior fossa pathology and there were no 'idiopathic' cases observed. The preceding posterior fossa disease or intervention suggests that the aetiology is likely to involve an inflammatory process resulting in altered compliance of the fourth ventricle. All patients with DLCFV characteristically present with cerebellar symptoms of nausea, ataxia and often had nystagmus. DLCFV was often associated with particularly patulous foramen of Lushka on magnetic resonance imaging (MRI), and importantly, all patients had communicating hydrocephalus with a patent aqueduct of Sylvius.

\section{DLCFV versus the trapped fourth ventricle}

Clinically, DLCFV and syndrome of the isolated (or trapped) fourth ventricle (TFV) present in a similar fashion. Distinguishing DLCFV from TFV is a critically important. TFV is a form of non-communicating hydrocephalus for which the treatment is very different; it may require a separate shunt into the fourth ventricle and/or additional open/endoscopic procedures to ensure the fourth ventricle communicates with either the third ventricle and/or the subarachnoid space [16]. If applied to patients with TFV (or other noncommunicating forms of hydrocephalus), the low-pressure CSF drainage described in this series could result 
in severe differential transtentorial pressures, leading to lower cranial nerve palsies and ataxia (referred to a Transtentorial Distortion Syndrome). MRI with CSF flow studies can confirm if there is flow within in aqueduct for cases that are difficult to differentiate.

\section{Management of DLCFV}

If there is doubt over the initial diagnosis of DLCFV, confirmatory testing may be performed through a temporary EVD. Symptomatic and radiological improvement should be experienced when the drain is set at progressively lower pressures; sometimes as low as $-20 \mathrm{~cm} \mathrm{H}_{2} \mathrm{O}$. An initial very low pressure setting may encourage return of the ventricles to normal size, required due to pressure-volume hysteresis curve [17]. In addition to establishing the pressures required for symptomatic and radiological improvement, temporary external drainage is also useful for differentiating between DLCFV and the syndrome of TFV [16], and in providing reassurance that there is patent CSF drainage when the ventricles do not come down.

In our experience, DLCFV does not respond to VPS. This may be because our initial shunt management was with a programmable system incorporating an anti-siphon device that would have been unable to generate the low CSF pressure required to resolve the condition, as demonstrated by progressive lowering of EVD drainage pressure. Successful management required the establishment of a low-pressure system (often negative pressure system), for example via a ventriculopleural shunt that is able to generate negative pressures during inspiration.

Finally, we caution against attributing the initial lack of response to shunting to shunt failure. Such patients are at risk of being exposed to multiple and unnecessary VPS revisions if early low-pressure CSF diversion is not considered.

\section{Literature review}

Since the initial reports by Zimmerman et al. from the USA [15], DLCFV has almost exclusively been reported in the Japanese literature. A literature search revealed a total of 22 cases from 14 manuscripts. Those with sufficient English language reporting are summarised in Table 2. The patients presented in the literature seem to have a number of characteristics in common with those presented in the current series. Firstly, a number of them have had previous neurosurgical pathology, either in the posterior fossa or due to subarachnoid and intraventricular haemorrhage. Secondly, the clinical presentation is consistent with the features of DLCFV, namely cerebellar signs in addition to the traditional signs and symptoms of hydrocephalus.

\begin{tabular}{|c|c|c|c|c|c|c|}
\hline Reference & Case & Aetiology & $\begin{array}{l}\text { Clinical } \\
\text { Presentation }\end{array}$ & Radiological Presentation & $\begin{array}{l}\text { Initial } \\
\text { Treatment }\end{array}$ & $\begin{array}{l}\text { Definitive } \\
\text { Treatment }\end{array}$ \\
\hline $\begin{array}{l}\text { Yamashita et al., } \\
2012 \text { [2] }\end{array}$ & $44 \mathrm{~F}$ & $\begin{array}{l}\text { SAH due to right } \\
\text { vertebral artery } \\
\text { dissecting } \\
\text { aneurysm + VPS }\end{array}$ & $\begin{array}{l}\text { Presented with } \\
\text { headache, nausea, } \\
\text { vomiting and } \\
\text { truncal ataxia }\end{array}$ & $\begin{array}{l}\text { Diffuse ventricular enlargement with } \\
\text { valve opening pressure at } 115 \mathrm{~mm} \mathrm{H}_{2} \mathrm{O} \\
\text { and DLCFV on reduction of opening } \\
\text { pressure to } 45 \mathrm{~mm} \mathrm{H}_{2} \mathrm{O}+\mathrm{C} 1-\mathrm{C} 7 \\
\text { Syringomyelia }+\mathrm{C} 6-\mathrm{T} 2 \text { anterior intradural } \\
\text { arachnoid cyst }\end{array}$ & VPS & $\begin{array}{l}\text { Additional } \\
\text { fourth } \\
\text { ventricular- } \\
\text { peritoneal } \\
\text { shunt with } \\
\text { independent } \\
\text { pressure } \\
\text { control }\end{array}$ \\
\hline $\begin{array}{l}\text { Katano et } \\
\text { al., } 2012 \text { [3] }\end{array}$ & $\begin{array}{l}6 \mathrm{Wk} \\
\mathrm{F}\end{array}$ & $\begin{array}{l}\text { Menıngomyelocele } \\
\text { repair + VPS }\end{array}$ & $\begin{array}{l}\text { Poor agility, grim- } \\
\text { face, occasional } \\
\text { choking on milk } \\
\text { and downward } \\
\text { gaze. }\end{array}$ & DLCFV + Cervical syringomyelia & - & $\begin{array}{l}\text { Reduction of } \\
\text { Strata NSC } \\
\text { valve setting } \\
\text { from } 1.5 \text { to } 1.0\end{array}$ \\
\hline $\begin{array}{l}\text { Hagihara } \\
\text { and Sakata } 2007 \\
\text { [4] }\end{array}$ & 13M & Unknown & $\begin{array}{l}\text { Headache, nausea, } \\
\text { gait disturbance, } \\
\text { truncal ataxia, } \\
\text { nystagmus and } \\
\text { incontinence }\end{array}$ & DLCFV + Whole spine syringomyelia & - & VPS \\
\hline $\begin{array}{l}\text { Shose et } \\
\text { al., } 1991 \text { [8] }\end{array}$ & $39 \mathrm{M}$ & $\begin{array}{l}\text { AVM resection (? } \\
\text { location) + VPS }\end{array}$ & $\begin{array}{l}\text { Altered } \\
\text { consciousness, } \\
\text { diplopia, rotatory } \\
\text { nystagmus, } \\
\text { drowsiness, } \\
\text { truncal ataxia and } \\
\text { Parinaud's sign }\end{array}$ & DLCFV & $\begin{array}{l}\text { EVD with } \\
\text { ventricular } \\
\text { collapse and } \\
\text { symptomatic } \\
\text { improvement } \\
\text { (? level) }\end{array}$ & VPS \\
\hline
\end{tabular}




\section{Cureus}

\begin{tabular}{|c|c|c|c|c|c|c|}
\hline $\begin{array}{l}\text { Toriyama et al., } \\
1991 \text { [10] }\end{array}$ & $27 \mathrm{M}$ & $\begin{array}{l}\text { Traumatic ICH + } \\
\text { IVH + VPS }\end{array}$ & $\begin{array}{l}\text { Nausea, vomiting, } \\
\text { altered } \\
\text { consciousness and } \\
\text { nystagmus }\end{array}$ & DLCFV & - & $\begin{array}{l}\text { Fourth } \\
\text { ventricular- } \\
\text { peritoneal } \\
\text { shunt }\end{array}$ \\
\hline $\begin{array}{l}\text { Okabe et } \\
\text { al., } 1990 \text { [11] }\end{array}$ & $21 \mathrm{M}$ & $\begin{array}{l}\text { Multiple IVH from } \\
\text { parietal AVM + } \\
\text { VPS }\end{array}$ & $\begin{array}{l}\text { Altered } \\
\text { consciousness, } \\
\text { bilateral exotropia }\end{array}$ & DLCFV & -- & $\begin{array}{l}\text { Revision of } \\
\text { VPS }\end{array}$ \\
\hline $\begin{array}{l}\text { Okabe et } \\
\text { al., } 1990 \text { [11] }\end{array}$ & $66 \mathrm{~F}$ & $\begin{array}{l}\text { SAH + IVH due to } \\
\text { right MCA } \\
\text { aneurysm }\end{array}$ & $\begin{array}{l}\text { Altered } \\
\text { consciousness, } \\
\text { bilateral exotropia }\end{array}$ & DLCFV & - & $\begin{array}{l}\text { No } \\
\text { improvement } \\
\text { despite VPS + } \\
\text { LPS + VPS } \\
\text { revision. } \\
\text { Patient died }\end{array}$ \\
\hline $\begin{array}{l}\text { Matsumoto et } \\
\text { al., } 1983 \text { [13] }\end{array}$ & $24 \mathrm{M}$ & $\begin{array}{l}\text { Post lumbar } \\
\text { discectomy }\end{array}$ & $\begin{array}{l}\text { Nystagmus, } \\
\text { Parinaud's sign, } \\
\text { truncal ataxia and } \\
\text { symptoms typical } \\
\text { of hydrocephalus }\end{array}$ & DLCFV & - & VPS \\
\hline $\begin{array}{l}\text { Matsumoto et } \\
\text { al., } 1983 \text { [13] }\end{array}$ & $22 \mathrm{~F}$ & SAH & $\begin{array}{l}\text { Nystagmus, } \\
\text { Parinaud's sign, } \\
\text { truncal ataxia and } \\
\text { symptoms typical } \\
\text { of hydrocephalus }\end{array}$ & DLCFV & - & VPS \\
\hline $\begin{array}{l}\text { Zimmerman et } \\
\text { al., } 1978 \text { [15] }\end{array}$ & $43 \mathrm{M}$ & Unknown & $\begin{array}{l}\text { Headaches, gait } \\
\text { ataxia and } \\
\text { nystagmus }\end{array}$ & DLCFV & - & VPS \\
\hline $\begin{array}{l}\text { Zimmerman et } \\
\text { al., } 1978 \text { [15] }\end{array}$ & $10 \mathrm{~F}$ & $\begin{array}{l}\text { Intrauterine rubella } \\
\text { and congenital } \\
\text { hydrocephalus }\end{array}$ & $\begin{array}{l}\text { Behavioural } \\
\text { abnormalities and } \\
\text { gait/balance } \\
\text { problems }\end{array}$ & DLCFV & VPS & $\begin{array}{l}\text { Fourth } \\
\text { ventricular- } \\
\text { peritoneal } \\
\text { shunt }\end{array}$ \\
\hline
\end{tabular}

TABLE 2: Presenting aetiology, symptoms and treatment of nine patients reported in the literature with DLCFV.

DLCFV: Disproportionately large communicating fourth ventricle; SAH: Subarachnoid hemorrhage; VPS: Ventriculoperitoneal shunt; EVD: External ventricular drainage; LPS: Lumbopleural shunt; AVM: Arteriovenous malformation; ICH: Intracerebral haemorrhage; IVH: Intraventricular haemorrhage; MCA: Middle cerebral artery.

Management of the patients in the literature was varied, with most patients improving with standard VPS. Few studies reported the type of shunt and valve used and therefore, the pressure dynamics of those systems are unknown. It is important to consider that a standard differential pressure valve without an antisiphon device will generate negative pressures in the standing patient that might be sufficient to manage a proportion of these patients.

The use of additional shunts, such as fourth ventricular-peritoneal shunts, creates increasingly complex systems with increased risk of shunt failure and need for further operative interventions. In addition, the literature is limited by a heterogeneous definition of DLCFV; some authors report the phenomenon of DLCFV in cases where there is clear fourth ventricular outlet obstruction with a patent aqueduct and no 'disproportionate enlargement' of the fourth ventricle, which, in our opinion, is a separate entity of obstructive hydrocephalus and should be managed differently, such as with endoscopic third ventriculostomy $[5,14]$. The term DLCFV should be limited to patients with a patent CSF circulatory system (flow through the aqueduct and fourth ventricular outlets) and therefore a truly communicating hydrocephalus.

\section{Study strengths and limitations}

Whilst this study is limited by the small numbers, this is a rare condition in adults and this series of six patients is the largest on DCLFV to date. The complete and persistent resolution of symptoms after negative pressure CSF diversion was a consistent finding in a heterogeneous group of patients. 


\section{Conclusions}

This case series of six cases of DLCFV illustrates the importance of awareness of this condition in directing definitive management. Traditional VPS, even with a valve set at low pressures, may not result in symptomatic improvement and therefore, a systematic approach using temporary CSF diversion via an EVD to assess the pressures required for fourth ventricular collapse and corresponding symptomatic improvement prior to definitive treatment with either a vVPS, an LPS or ventriculopleural shunt seems to be the most pragmatic approach to these patients.

\section{Additional Information \\ Disclosures}

Human subjects: Consent was obtained by all participants in this study. Animal subjects: All authors have confirmed that this study did not involve animal subjects or tissue. Conflicts of interest: In compliance with the ICMJE uniform disclosure form, all authors declare the following: Payment/services info: Author AC is supported by a National Institute for Health Research (NIHR) Academic Clinical Fellowship. Financial relationships: All authors have declared that they have no financial relationships at present or within the previous three years with any organizations that might have an interest in the submitted work. Other relationships: All authors have declared that there are no other relationships or activities that could appear to have influenced the submitted work.

\section{References}

1. Keong NC, Czosnyka M, Czosnyka Z, Pickard JD: Clinical evaluation of adult hydrocephalus. Youmans Neurological Surgery, 6th Edition. Winn HR (ed): Saunders, 2011.

2. Yamashita T, Hiramatsu H, Kitahama Y, Tokuyama T, Sugiyama K, Namba H: Disproportionately large communicating fourth ventricle associated with syringomyelia and intradural arachnoid cyst in the spinal cord successfully treated with additional shunting. Neurol Med Chir. 2012, 52:231-234. 10.2176/nmc.52.231

3. Katano H, Matsuo S, Yamada K: Disproportionately large communicating fourth ventricle resulting from adjustable valve shunt in an infant. Acta Neurol Belg. 2012, 112:91-93. 10.1007/s13760-012-0031-3

4. Hagihara N, Sakata S: Disproportionately large communicating fourth ventricle with syringomyelia: case report. Neurol Med Chir. 2007, 47:278-281. 10.2176/nmc.47.278

5. Osaka Y, Shin H, Sugawa N, Yoshino E, Horikawa Y, Yamaki T, Ueda S: "Disproportionately large communicating fourth ventricle" due to membranous obstruction of Magendie's foramen (Article in Japanese). No Shinkei Geka. 1995, 23:429-433.

6. Kuroki T, Matsumoto M, Ohishi H, Yamashita K, Sugo N, Terao H, Kushida Y: Disproportionately large, communicating fourth ventricle; report of 4 cases (Article in Japanese). No Shinkei Geka. 1992, 20:707-711.

7. Ito S, Hara M, Asoh Y, Kadowaki C, Takeuchi K: A case of disproportionately large communicating fourth ventricle after resection of temporal astrocytoma that evolved an isolated fourth ventricle (Article in Japanese). No Shinkei Geka. 1991, 19:1161-1166.

8. Shose Y, Nogaki H, Kamikawa S: Disproportionately large communicating fourth ventricle: case report. Neurol Med Chir. 1991, 31:1003-1007. 10.2176/nmc.31.1003

9. Furuichi S, Nishijima M, Kurimoto M, Takaku A: A disproportionately large communicating fourth ventricle occurring after suboccipital craniectomy: report of two cases (Article in Japanese). No Shinkei Geka. 1991, 19:379-383.

10. Toriyama T, Kawauchi M, Koike J, Harada T, Murata A, Kyoshima K: A case of disproportionately large communicating fourth ventricle (DLCFV) combined with syringomyelia and Chiari malformation (Article in Japanese). No Shinkei Geka. 1991, 19:167-172.

11. Okabe S, Ogane K, Suzuki S, Iwabuchi T, Ottomo M: Disproportionately large communicating fourth ventricle with bilateral exotropia: report of two cases (Article in Japanese). No Shinkei Geka. 1990, 18:969973.

12. Bandoh K, Shimoji T, Maeda M, Nitta T, Ishii S: Disproportionately large communicating fourth ventricle. Report of two cases occurring after suboccipital craniectomy. Neurol Med Chir. 1987, 27:533-537. $10.2176 / \mathrm{nmc} .27 .533$

13. Matsumoto M, Kushida Y, Shibata I, Seiki Y, Terao H: Disproportionately large communicating fourth ventricle--report of 2 cases (Article in Japanese). No Shinkei Geka. 1983, 11:1185-1190.

14. Matsumura K, Yokosuka K, Takai H, Toi H, Matsushita N, Matsubara M, Uno M: A disproportionately large communicating fourth ventricle treated by endoscopic third ventriculostomy: a case report. Jpn J Neurosurg. 2014, 23:987-992. 10.7887/jcns.23.987

15. Zimmerman RA, Bilaniuk LT, Gallo E: Computed tomography of the trapped fourth ventricle. AJR Am J Roentgenol. 1978, 130:503-506. 10.2214/ajr.130.3.503

16. Harter DH: Management strategies for treatment of the trapped fourth ventricle . Child's Nerv Syst. 2004, 20:710-716. 10.1007/s00381-004-1004-5

17. Lesniak MS, Clatterbuck RE, Rigamonti D, Williams MA: Low pressure hydrocephalus and ventriculomegaly: hysteresis, non-linear dynamics, and the benefits of CSF diversion. Br J Neurosurg. 2002, 16:555-561. $10.1080 / 02688690209168360$ 